\title{
衝突回避操船のための情報収集に関する研究 ーアイカメラによる海技者の視線分析に基づく研究-
}

\author{
榊原 愛 $^{1} \cdot$ 内野 明子 $^{2} \cdot$ 小林 弘明 $^{3}$

\section{Analysis of Seafarers' Data Gathering for Avoiding Collision Utilizing Eye-tracking Technology}

\author{
Ai SAKAKIBARA, Akiko UCHINO and Hiroaki KOBAYASHI
}

\begin{abstract}
In collision avoiding maneuvers, the standard navigational procedures are stipulated by laws such as the International Regulation for Preventing Collisions at Sea. Based on such laws, well-experienced seafarers combine their normative approach they have developed through their experience in order to determine a corresponding course of action. Therefore, analyzing their procedures for avoiding collisions would provide us with valuable insights into judging the risk of collision with oncoming vessels. In addition, when reviewing such procedures, a rational basis for judging the risk of collision can be examined. With this in mind, the authors study well-experienced seafarers' lookout procedures for collision avoiding situations methodically set up by a ship-handling simulator. Especially in this study, eye-tracking technology is additionally utilized for detailed analyzing of seafarers' data gathering by their lookout procedures. Utilizing this technology enables concrete information for each encountering situation seafarers acquire by their visual inspections, radar observation and scanning with binoculars, to be revealed. The authors suggest such procedures would be beneficial when judging the risk of collision and would serve as a valuable perspective in education and training, teamwork.
\end{abstract}

Keywords : Ship Handling and Propelling, Collision Avoiding, Lookout, Eye-tracking Technology キーワード：操船・推進，衝突回避，見張り，視線追跡技術

\section{1. はじめに}

航行船舶との衝突回避における標準的な行動指 針は、海上衝突予防法等の規則に定められている。 しかし、実際に遭遇する状況は多様であり、海技者 は規則等を基準に、自らの経験を通して構築してき た行動規範と合わせて、行動方針を決定していると 考えられる。本論では、このような規範を有し、定 常的に安全運航を達成できている標準的な海技者の
行動を詳細に分析した。特に、見張りに関する行動 から、航行船との衝突の危険性を判断する際の情報 収集状況を分析し、その特性を検討した。検討にあ たって、航行船との遭遇状況に応じて海技者が注視 する対象を特定する必要がある。このことから、視 線追跡装置（以降、アイカメラ）を用いて、収集す る情報の種類とタイミング、量など、衝突回避にお ける海技者の情報収集特性を詳細に検討した。

1 学生会員 東京海洋大学大学院 (研究当時)

2 正会員 東京海洋大学大学院（广135-8533 東京都江東区越中島 2-1-6）uchino@kaiyodai.ac.jp

3 正会員 東京海洋大学（干135-8533 東京都江東区越中島 2-1-6）kobayasi@kaiyodai.ac.jp 


\section{2. 操船実験による検討}

\section{1 操船シミュレータにアイカメラを併用す る操船実験の実施}

見張りに関する行動を分析するため、東京海洋大 学海洋工学部のフル・ミッション型操船シミュレー 夕を用いて操船実験を行った。被験者は、定常的に 安全運航を達成できる標準的な海技者として、船社 より推薦された 5 名である。被験者には操船の際に アイカメラを装着してもらい、操船の開始から終了 までを通して視線の移動状況を計測した。視線の移 動状況は、被験者が注視する位置が背景を含めた映 像上に点で重畳して示寸形式で記録される。この記 録から注視した点に位置する情報について、その種 類や注視したタイミング、注視している時間等を抽 出した。また、船橋内での被験者の行動及び音声を 記録するため、船橋全体を映像で捉えられるようカ メラ 2 台を船橋の左右に設置し、被験者にはピンマ イクを装着した。また、レーダ/ARPA（Target Tracking と同義) の使用状況も録画することとした。 更に、操船シミュレータに記録される操舵及び機関 操作などの時系列データも検討に用いた。

実験に先立ち、被験者がアイカメラを装着する前 に、操船シミュレータの機能や船橋内の航海計器類 の取り扱い方法を説明した。また、操船シミュレー 夕実験でも実海域で操船する場合と同等の行動デー 夕を得るため、供試船であるコンテナ船の操縦性能 の把握とレーダ/ARPA 及び双眼鏡などの船橋設備の 使用の習熟を目的に、予め操船練習を行った。

\section{2 検討に用いた状況設定}

操船実験では、平均的な海技者ならば単独当直で も安定した安全運航が可能な状況設定（以降、シナ リオ）を 3 種類準備し、被験者全員に操船してもら った。図 1 に、シナリオの一例を示寸。被験者には、 வ印で示す位置より航行を開始して、破線で示寸計 画航路線を目安に必要な衝突回避を行って航行する ように依頼した。1 シナリオにつき、本船の航行に 強く干渉する船舶（以降、干渉船）が、赤色の $\Delta$ 印 及び矢印で示すように時間をおいて 3 回発生する。 周囲には、白抜きの $\triangle$ 印のように干渉の弱い船舶が 航行する。本船以外の船舶の出現については予め情 報を提供しておくことはせず、実際の操船における 遭遇と同等である。図 1 で示した以外の 2 種類のシ ナリオでは、同海域を航行して図 1 と類似した状況 が異なる順に出現する状況を設定した。被験者に詳

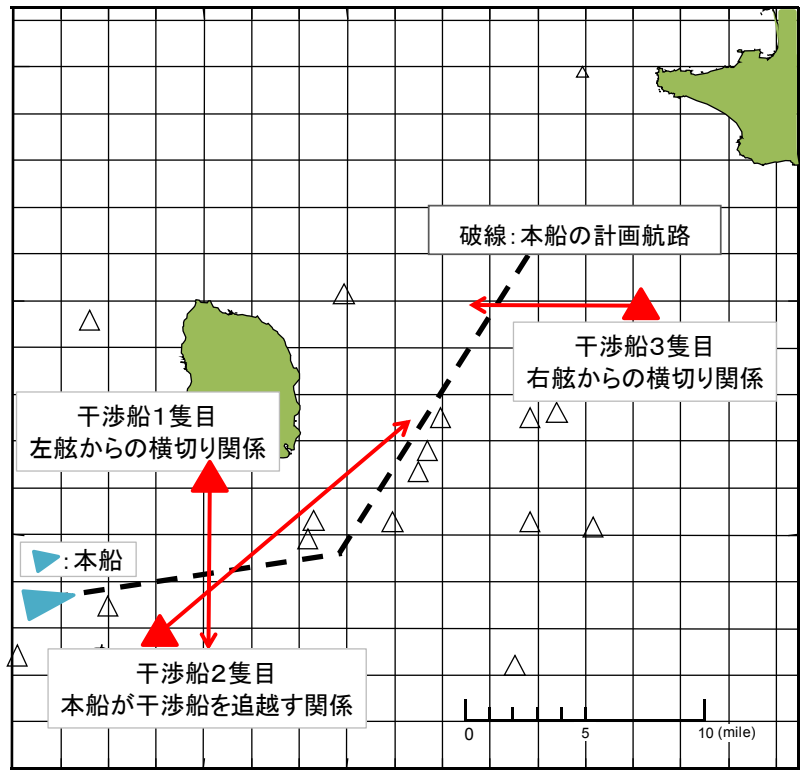

図 1 操船実験におけるシナリオの一例

細は異なるが類似した状況を繰り返して操船しても らうことで、航海環境に対する海技者の特性の抽出 に繋がると考えられる。故に、3 種類のシナリオを 用いることとした。図 1 以外の 2 種類のシナリオの 詳細は、紙面の制限から掲載しないこととする。

\section{3. 情報収集状況の分析方法}

\section{1 行動の分類と分析対象とする情報}

干渉船との衝突の回避に向けた情報の収集過程 を詳細に検討するため、まず、収集行動を分類する。 本論では、収集行動を表 1 に示すV、RT、RR、PF の 4 種類に大別 ${ }^{(1)}$ することとした。Vは、肉眼及び双眼 鏡による目視またはコンパスによる方位の計測で、 人間の視覚により行う見張りの行動に分類する。RT は、レーダ/ARPA 上に表示される情報を用いて、真 運動表示ベクトルを基に見張りを行う行動とする。

表 1 情報収集に関する行動の分類

\begin{tabular}{|c|c|}
\hline 分類 & 内容 \\
\hline V & $\begin{array}{l}\text { 肉眼や双眼鏡で目視する、または、 } \\
\text { コンパスで方位を計測する見張り }\end{array}$ \\
\hline RT & $\begin{array}{l}\text { レーダ/ARPA を用いた } \\
\text { 真運動表示ベクトルに基づく見張り }\end{array}$ \\
\hline $\mathrm{RR}$ & $\begin{array}{l}\text { レーダ/ARPAを用いた } \\
\text { 相対運動表示ベクトルに基づく見張り }\end{array}$ \\
\hline $\mathrm{PF}$ & 船位推定 \\
\hline
\end{tabular}


同じレーダ/ARPA を用いる見張りでも、相対運動 表示ベクトルに基づく見張りの行動は、RR に分類す る。ただし、上記に挙げたレーダやコンパス等を使 用する行動でも、その目的が見張りの場合だけでな く、船位推定の場合も考えられる。このため、海図 作業の有無など、前後の行動との関係から船位推定 と識別される場合は、PFに分類することにした。

これらの V、RT 及び RR に分類される見張りの行 動より得られる情報の項目として、ベクトル(以降、 vector)、方位 (以降、bearing)、距離(以降、distance)、 針路（以降、course）及び速力（以降、speed）に加 え、本船との相対的運動関係を示寸最接近時間（以 降、TCPA）及び最接近距離（以降、DCPA）の 7 種類 を本論での検討対象とした。

\section{2 情報収集量の評価}

アイカメラでは、被験者が視覚を通して得る映像 が断続的に $(30 \mathrm{~Hz}: 1$ 秒間に 30 回）記録される。情 報の収集状況を詳細に分析するには、この映像記録 から被験者が収集している情報を特定する必要 ${ }^{(2)}$ が ある。このため、各収集行動の実施に要する時間長 さや実施頻度に着目寸る。これらの值は、情報の衝 突回避に関する判断への必要性と密接に関連してい ると考えられる。故に、V 及びRT、RRに分類される 行動は、各行動 1 回の実施に要する時間も計測する。 しかし、1 項目の情報の収集に要する時間は、情報 の種類や収集手段によって異なる。このため、各行 動から得られる情報に、表 2 に示寸収集方法及び評 価基準に基づく相対的な評価值を設定することにし た。評価值は、1 回の行動で確実に 1 項目の情報を 取得できると推定される場合を 1 とし、これを基準 に新たな評価值 ${ }^{(3)}$ を設定した。この評価值を情報収 集量と呼ぶこととし、分析対象を絞り込む際に重点 をおいて収集された情報であると評価する指標に用 いることにした。情報収集量の評価值は、表 2 に示 すとおり、情報収集に関する行動の分類と収集方法 により異なる。詳細は次のとおりである。

まず、分類 $\mathrm{V}$ は、「肉眼や双眼鏡で目視する、ま たは、コンパスで方位を計測する見張り」の行動で ある。このうち、コンパスを用いる見張りでは、被 験者は干渉船の bearing を明確な数值で計測する。 一方、同じ分類 $\mathrm{V}$ の行動でも、肉眼や双眼鏡による 見張りでは、何の情報を取り込んでいるのかを被験 者以外が特定することは難しい。この状況を考慮し て、肉眼や双眼鏡による目視では、干渉船の bearing、
表 2 情報収集量の評価

\begin{tabular}{|c|c|c|c|}
\hline 分類 & 収集方法 & 評価基準 & 評価 \\
\hline \multirow{5}{*}{ V } & \multirow{2}{*}{$\begin{array}{l}\text { コンパスによる } \\
\text { bearing の計測 }\end{array}$} & 1 回 & 1 \\
\hline & & 2 回以上 & 2 \\
\hline & \multirow{3}{*}{$\begin{array}{c}\text { 肉眼や双眼鏡 } \\
\text { による目視 }\end{array}$} & bearing $(0.5)$ & \multirow{3}{*}{1.5} \\
\hline & & course $(0.5)$ & \\
\hline & & distance $(0.5)$ & \\
\hline \multirow{2}{*}{$\begin{array}{l}\mathrm{RT} \\
\text { 及び } \\
\mathrm{RR}\end{array}$} & \multirow{2}{*}{$\begin{array}{l}\text { レーダ/ARPA 上 } \\
\text { の数值または } \\
\text { ベクトルの確認 }\end{array}$} & 0.5 秒以上 & 1 \\
\hline & & $\begin{array}{c}1 \text { 秒以上 } \\
\text { かつ複数回 }\end{array}$ & 2 \\
\hline
\end{tabular}

course 及び distance の何れの情報もある程度把握 していると考え、表 2 のように各情報の評価值を 0.5 と仮定し、これを合計した 1.5 の情報収集量を収集 していると評価することにした。また、コンパスに よる bearing の計測では、1 回の行動で確実に 1 項 目の情報を取得できることから、計測回数に応じた 評価值を設定することにした。

次に、分類 RT 及びRR である。これは、レーダ/ARPA 上に表示される情報を用いる見張りの行動である。 前者は真運動表示ベクトルに基づいて、後者は相対 運動表示ベクトルに基づいて行われる。得られる情 報は、レーダ/ARPA のレーダ上に表示される vector に加え、本船に対する干涉船の bearing、 distance、 course 及び speed、TCPA 及び DCPA の 6 種類の数值 によるARPA データである。一般に、人間が視覚によ り特定の対象を認識する時、約 0.2 から 0.3 秒間に 渡って対象に視線を固定して注視すると言われてい る。また、特に注意を払って注視する場合は、その

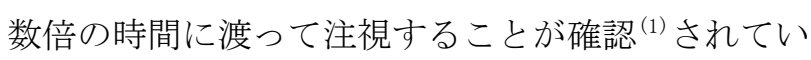
る。このことから、特定の情報を注視し続ける行動 や繰り返し注視する行動では、被験者は、衝突回避 に関する判断に必要性が高い情報として収集してい ると考えられる。したがって、RT 及び RR に分類さ れる行動の評価では、表 2 に示すとおり、注視する 時間または回数を用いることとし、0.5 秒以上 1 秒 以下の注視から得られる情報は 1 と評価し、1 秒以 上を掛けて複数回に渡って確認する情報は 2 と評価 することにした。

以上に述べたように、見張りの行動より得られる 情報を予め評価した。そして、評価值が 2 以上とな った行動から得る情報は重点的に収集されていると 判別し、詳細に検討する対象とした。 


\section{3 フェーズによる情報収集過程の分割}

検討する情報収集過程は、干涉船を初認した時点 から干渉船を回避する行動を開始する時点までの範 囲とした。情報の収集状況は、衝突回避に関する判 断の進行に応じて変化すると考えられる。このこと から、一連の情報収集過程を経過時間で正規化して 3 段階のフェーズ ${ }^{(4)} に$ 分割し、検討を進めることに した。正規化は、干渉船を初認した時点を 1、回避 する行動を開始する時点を 0 として行った。更に、 1 から 0.8 の区間を「初認フェーズ」、0.8から 0.2 の 区間を「継続監視フェーズ」とし、0.2 から 0 の区 間を「避航行動開始直前フェーズ」と名付けて定義 することにした。

\section{4 見合い関係による種別}

干渉船との衝突を回避するために収集する情報 は、見合い関係に応じて異なると考えられる。この ことから、前節に挙げたフェーズによる分割に加え、 見合い関係による収集情報の差異を予婤査するこ とにした。表 3 は、一例として、初認フェーズで収 集した全ての情報において 7 種類の各情報項目

(vector, bearing, distance, course, speed, DCPA, TCPA）が占める割合を見合い関係毎に示したもので ある。表 3 で、干渉船が右舷からの横切り船という 関係では、vector、bearing 及びdistance の順に割 合が高い一方、行会い船ではvector は $0 \%$ で bearing、 distance 及び course の割合が高く、見合い関係に 応じて収集する情報が異なることが分かる。故に、 各フェーズ及び各見合い関係において、収集する割 合が高い上位 3 種の情報項目を重点的に収集された 情報項目として扱うことにした。

\section{4. 標準的海技者の情報収集特性}

検討を行うにあたり、干渉船との衝突を回避する ために必要な情報項目について予め仮説を立て、被 験者による情報収集状況と比較して、標準的海技者 の情報収集特性を検討することとした。

\section{1 フェーズにおける情報収集の目的}

必要な情報項目を検討するにあたり、各フェーズ における情報収集の目的を次のとおり仮定した。

「初認フェーズ」は、干渉船を初めて認識し、継 続的に監視する必要性があるかどうかを判断する段 階である。このため、干渉船の現在状況を把握して、 本船との将来状況を予測することを目的とした。
表 3 収集した情報の割合と見合い関係による比較 初認フェーズにおける情報収集状況

\begin{tabular}{|c|c|c|c|c|c|}
\hline \multicolumn{2}{|c|}{ 初認フェーズ } & $\begin{array}{l}\text { 右舷から } \\
\text { の横切り }\end{array}$ & $\begin{array}{l}\text { 左舷から } \\
\text { の横切り }\end{array}$ & 追越し船 & 行会い船 \\
\hline \multirow{7}{*}{$\begin{array}{l}\text { 情 } \\
\text { 報 } \\
\text { 項 } \\
\text { 目 }\end{array}$} & vector & $23 \%$ & $14 \%$ & $4 \%$ & $0 \%$ \\
\hline & bearing & $19 \%$ & $28 \%$ & $18 \%$ & $34 \%$ \\
\hline & distance & $19 \%$ & $29 \%$ & $18 \%$ & $33 \%$ \\
\hline & course & $15 \%$ & $29 \%$ & $23 \%$ & $33 \%$ \\
\hline & speed & $8 \%$ & $0 \%$ & $9 \%$ & $0 \%$ \\
\hline & TCPA & $8 \%$ & $0 \%$ & $14 \%$ & $0 \%$ \\
\hline & $\overline{\mathrm{DCPA}}$ & $8 \%$ & $0 \%$ & $14 \%$ & $0 \%$ \\
\hline
\end{tabular}

続く「継続監視フェーズ」は、前フェーズで予測 した本船との将来状況において変化の有無を確認す る段階である。故に、干渉船の継続的な動静監視か ら行動変化を把握し、本船との将来状況の変化を把 握することを目的とした。更に、「避航行動開始直前 フェーズ」は、避航を行動に移寸直前に、避航方法 を決定する段階である。従って、干渉船の動静に変 化が無いかどうかを再度確認し、開始タイミングを 含めた行動の内容を決定することを目的とした。こ れらの目的は、見合い関係に関わらず、避航のため に必要な手順であり、共通であると考えられる。

各目的の達成に必要な情報項目は、「初認フェー ズ」及び「継続監視フェーズ」では見合い関係に関 わらず共通である一方、「避航行動開始直前フェー ズ」では、見合い関係によって異なると考えられる。 なぜなら、見合い関係に応じて避航の方法は異なり、 確認する必要がある情報が異なるためである。

避航の方法は、本船に対する干渉船が 1 隻の場合 と、複数隻の場合とでは異なると考えられる。隻数 による違いは、順に考察する。

\subsection{1 隻対 1 隻の危険な干渉関係にある船舶 に対する情報収集の特性}

1 隻対 1 隻で危険な干渉関係にある船舶に対し、 衝突回避のために行う情報収集について述べる。検 討にあたり、各フェーズにおける情報収集について、 4.1 節で述べた目的の達成に必要と考えられる情報 項目を列挙し、操船実験において被験者が収集した 情報の割合と比較して検討した。

\section{（1）初認フェーズ}

初認フェーズにおける情報収集の目的は 4.1 節で 述べたとおり仮定した。この内容を下記(1)及び(2)の とおり細分化し、各目的の達成に（ ）内の情報項目 
が必要であると仮説を立てた。(1)の達成に向けて、 bearing 及びdistance からは本船からの干渉船の方 位と距離を把握でき、vector からは干渉船の本船に 対する相対的運動関係を把握できる。また、(2)の達 成に向け、DCPA からは将来の干渉関係を直接的に把 握することができる。故に、各々の目的達成に、（ ） 内の情報項目が必要であると仮定した。

(1)現在状況の把握

(vector, bearing, distance)

(2)将来状況の予測

(DCPA)

先の 3.4 節で挙げた表 3 は、操船実験における海 技者の情報収集状況で、収集された情報項目の割合 を見合い関係毎に示したものである。值は、被験者 5 名の平均值である。

表 3 より、(1)「現在状況の把握」の達成に必要な 情報項目として仮定した bearing、distance 及び vector は、右舷からの横切り船の関係において海技 者が重点的に収集した情報の上位 3 項目と一致して いることがわかる。しかし、左舷からの横切り船、 追越し船及び行会い船の関係では、3 項目のうちの bearing と distance は重点的に収集された一方、 vector の割合は低いという結果であった。また、(2)

「将来状況の予測」の達成に必要な情報として挙げ たDCPA が収集された割合は、見合い関係に関わらず 低いという結果であった。左舷からの横切り船と行 会い船の関係では全く収集されなかった。

\section{(2) 継続監視フェーズ}

継続監視フェーズにおける情報収集の目的は 4.1 節のとおり仮定した。初認フェーズと同様に、更に 下記(3)及び(4)のとおり細分化し、各目的の達成に( ) 内の情報項目が必要であると仮説を立てた。(3)の達 成に向けて、vector または course からは、干渉船 の動静の変化を知ることができる。また、(4)の達成 に向けては、DCPA を確認することにより、干渉関係 の変化を直接的に把握することができる。故に、各々 の目的達成に、（）内の情報項目が必要であると仮 定した。

\section{(3)干渉船の行動変化の把握}

(vector または course)

(4)将来状況の変化の把握

(DCPA)

初認フェーズと同様に、操船実験における海技者 の情報収集において、継続監視フェーズで収集され
表 4 収集した情報の割合と見合い関係による比較 継続監視フェーズにおける情報収集状況

\begin{tabular}{|c|c|c|c|c|c|}
\hline \multicolumn{2}{|c|}{$\begin{array}{l}\text { 継続監視 } \\
\text { フェーズ }\end{array}$} & $\begin{array}{l}\text { 右舷から } \\
\text { の横切り } \\
\text { 船 }\end{array}$ & $\begin{array}{l}\text { 左舷から } \\
\text { の横切り } \\
\text { 船 }\end{array}$ & 追越し船 & 行会い船 \\
\hline \multirow{7}{*}{$\begin{array}{l}\text { 情 } \\
\text { 報 } \\
\text { 項 } \\
\text { 目 }\end{array}$} & vector & $21 \%$ & $33 \%$ & $22 \%$ & $0 \%$ \\
\hline & bearing & $18 \%$ & $33 \%$ & $9 \%$ & $34 \%$ \\
\hline & distance & $14 \%$ & $17 \%$ & $13 \%$ & $33 \%$ \\
\hline & course & $15 \%$ & $17 \%$ & $18 \%$ & $33 \%$ \\
\hline & speed & $10 \%$ & $0 \%$ & $4 \%$ & $0 \%$ \\
\hline & TCPA & $10 \%$ & $0 \%$ & $17 \%$ & $0 \%$ \\
\hline & DCPA & $12 \%$ & $0 \%$ & $17 \%$ & $0 \%$ \\
\hline
\end{tabular}

た情報項目の割合を見合い関係毎に表 4 に示す。值 は、被験者 5 名の平均值である。

表 4 より、(3)「干渉船の行動変化の把握」の達成 に必要な情報項目として仮定した vector または course は、何れの見合い関係においても海技者が重 点的に収集した情報の上位 3 項目に含まれることが わかる。一方、(4)「将来状況の変化の把握」の達成 に必要な情報項目に挙げた DCPA の割合は、右舷から の横切り船や追越し船の関係では収集されたものの 低い割合で、左舷からの横切り船及び行会い船では 全く収集されなかった。

初認フェーズにおける情報収集の目的として仮 定した(2)「将来状況の予測」と、継続監視フェーズ における情報収集の目的として仮定した(4)「将来状 況の変化の把握」では、目的の達成に必要な情報項 目は、共通にDCPA であると仮説を立てた。しかし、 操船実験より得られた情報収集状況では、どちらの フェーズにおいても収集の割合は低いという結果で あった。このことについて考察する。

大型船舶における安全運航の維持には、周囲を航 行する船舶との将来的な干渉関係の推定が不可欠で ある。目的の達成に必要な情報項目として仮説で挙 げた DCPA に代わり、(2)及び(4)の目的の達成に繋がる 別の情報を収集していることが考えられる。

表 3 及び表 4 から、横切り船及び行会い船の関係 では、収集の割合が他と比較して概ね高かった情報 項目に bearing がある。bearing が DCPAに代わる別 の指標として収集された可能性が考えられる。

一般に、 bearing の変化を継続的に観測すること により、将来状況は推定できると言われている。ま た、bearingは、DCPAに比べて確認が容易である。 これらの影響から、海技者が DCPA の代わりに bearing の情報を積極的に収集した結果、収集の割 
合が比較的高い結果となったことが考えられる。こ のことについて、 bearing が DCPA に代わって将来の 干渉関係の推定に有効な指標となりうるかを検討す ることにした。

bearing は、本船と干渉船との針路交差角に応じ て変化する。考察のため、干渉船と本船との針路交 差角を系統的に設定し、干渉船と本船とが衝突する と仮定した地点から共通に 3 マイルの初期位置から 接近して、本船の前方 0.5 マイルを航過する場合と 後方 0.5 マイルを航過する場合の時間経過による bearing の変化を計算により求めた。図 2 は、針路 交差角が 22.5 度の場合と 157.5 度の場合を比較のた めに並べて示したものである。横軸の時間経過に対 し、縦軸には初期位置からの bearing の変化量を示 す。図 2 より、bearing の変化は一定ではない上、 針路交差角により変化のタイミングおよび量が大き く異なることがわかる。海技者が bearing の変化を 認識するには、ある程度の変化量が必要である。図 2 より、針路交差角が 22.5 度の場合、経過時間が 2 分程度で変化が有ることを認識できると考えられる。 一方、針路交差角が 157.5 度の場合、10 分以上経過 しないと bearing は明確には変化しない上、前方航 過ではその後急激に変化する。すなわち、本船と干 渉船との針路交差角により変化する bearing のみで は、的確な推定は難しいことがあると考えられる。

したがって、将来の干渉関係を推定するには、干 渉関係が変化する特性に応じて目的に合致する複数 の情報を組み合わせて収集し、確認することが重要 であると考えられる。

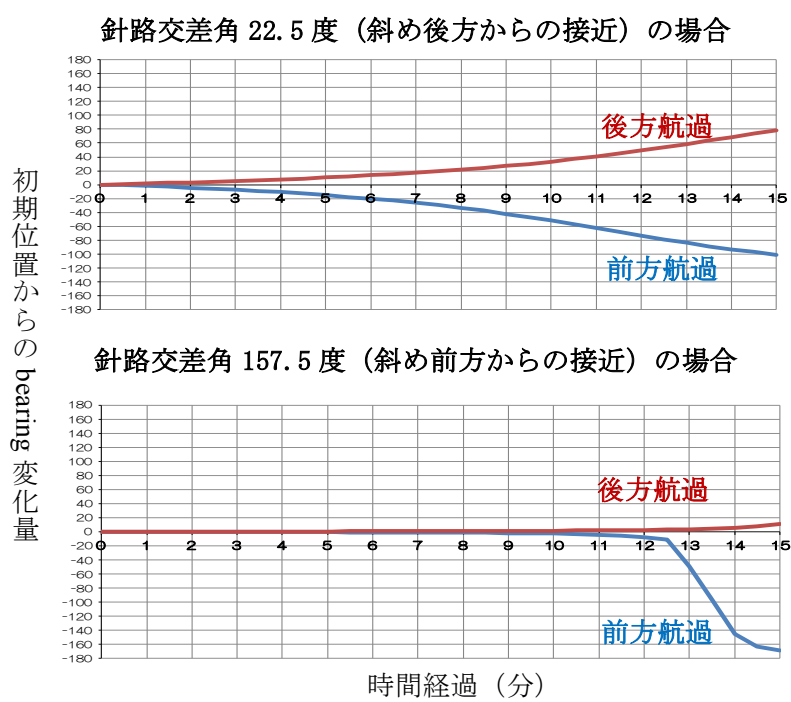

図 2 時間経過による bearing の変化の比較
（3）避航行動開始直前フェーズ

このフェーズにおける情報収集は、4.1 節で述心゙ たとおり、目的は共通でも、その達成に必要な情報 項目は見合い関係に応じて異なると考えられる。

故に、筆者らは、表 5 に示寸とおり、見合い関係 に応じて、目的の達成に必要な情報項目について仮 説を立てた。干渉船の行動変化の有無は、vector ま たは course を観測することで確認できる。そして、 避航行動を開始するタイミングは、危険な状況が発 生するまでの残時間に応じて決定されることから、 TCPA または distance を観測することで可能になる と考えられる。また、避航行動の内容は、本船と干 渉船との相対的運動関係に応じて決定することから、 横切り船の場合は bearing を、追い越し船及び行会 い船の場合は vector または DCPA を観測により可能 になると考えられる。

表 6 は、操船実験により、避航行動開始直前フェ ーズにおいて収集された情報項目の割合を示したも のである。表 5 との比較から、表 5 に挙げた情報収 集の目的とその達成に必要な情報項目に対して、海 技者が収集した情報項目は概ね一致するという結果 を得た。避航行動開始直前フェーズでは、収集の目

表 5 避航行動開始直前フェーズにおける情報収集 の目的とその達成に必要な情報項目

\begin{tabular}{|c|c|c|c|c|}
\hline \multirow{2}{*}{ 情報収集の目的 } & \multicolumn{4}{|c|}{ 目的の達成に収集の必要な情報項目 } \\
\cline { 2 - 5 } & $\begin{array}{c}\text { 右舷から } \\
\text { 横切り } \\
\text { 船 }\end{array}$ & $\begin{array}{c}\text { 左舷から } \\
\text { の横切り } \\
\text { 船 }\end{array}$ & 追越し船 & 行会い船 \\
\hline $\begin{array}{c}\text { 干涉船の } \\
\text { 行動変化の有無 } \\
\text { の確認 }\end{array}$ & vector & vector & vector & vector \\
\hline $\begin{array}{c}\text { 避航行動の } \\
\text { 開始タイミング } \\
\text { の決定 }\end{array}$ & TCPA & course & course & course \\
\hline $\begin{array}{c}\text { 避航行動内容 } \\
\text { の決定 }\end{array}$ & bearing & bearing & distance & distance \\
\cline { 3 - 5 } & vector & vCPA & vector \\
\hline
\end{tabular}

表 6 収集した情報の割合と見合い関係による比較 避航行動開始直前フェーズにおける情報収集状況

\begin{tabular}{|c|c|c|c|c|c|}
\hline \multicolumn{2}{|c|}{$\begin{array}{l}\text { 避航行動開始 } \\
\text { 直前フェーズ }\end{array}$} & $\begin{array}{c}\text { 右舷から } \\
\text { の横切り } \\
\text { 船 }\end{array}$ & $\begin{array}{c}\text { 左舷から } \\
\text { の横切り } \\
\text { 船 }\end{array}$ & 追越し船 & 行会い船 \\
\hline \multirow{4}{*}{$\begin{array}{c}\text { 情 } \\
\text { 報 }\end{array}$} & vector & $16 \%$ & $16 \%$ & $17 \%$ & $21 \%$ \\
\cline { 2 - 6 } & bearing & $19 \%$ & $17 \%$ & $11 \%$ & $20 \%$ \\
\cline { 2 - 6 } & distance & $18 \%$ & $17 \%$ & $11 \%$ & $22 \%$ \\
\cline { 2 - 6 } 目 & course & $10 \%$ & $8 \%$ & $11 \%$ & $22 \%$ \\
\cline { 2 - 6 } & speed & $11 \%$ & $8 \%$ & $6 \%$ & $5 \%$ \\
\cline { 2 - 6 } & TCPA & $13 \%$ & $17 \%$ & $22 \%$ & $5 \%$ \\
\cline { 2 - 6 } & DCPA & $13 \%$ & $17 \%$ & $22 \%$ & $5 \%$ \\
\hline
\end{tabular}


的は共通でも、見合い関係に応じて必要とする情報 項目は異なることを確認した。

\subsection{1 隻対 2 隻の危険な干渉関係にある船舶 に対する情報収集の考察}

4.2 で述べた 1 隻対 1 隻の危険な干渉関係におけ る情報収集の特性は、衝突回避における情報収集を 検討する際の基準になると考えられる。海技者が実 際に遭遇する状況は多様であることから、干渉船が 複数隻となる場合は、これらを基準に検討寸る。

本論では、干渉船が 2 隻同時並行に発生する場合 について考察する。対象となる 1 隻対 2 隻の干渉関 係は、 1 シナリオあたり 3 隻の干渉関係を設定した 3 種類のシナリオを 5 名の被験者に操船してもらった 全 45 ケース $(3 \times 3 \times 5=45$ ケース $)$ の干渉関係のう ち、14 ケース存在した。1 隻対 1 隻での情報収集と 比較するため、海技者が 2 隻の干渉船に衝突の可能 性が有ることをほぼ同時に認識し、情報を収集し始 めて1隻ずつ避航する1ケースを取上げて考察する。

なお、 1 隻対 2 隻の干渉関係における情報収集状 況については、4.2 で挙げた「収集した情報項目の 割合」に加え、1 回の情報収集に要する「平均所要 時間」、単位時間あたりの「情報収集行動の回数」と

「情報収集量」、「情報収集方法の割合」を併せて考 察することにした。同時並行の監視が必要な干渉船 が増えることは、1 隻を監視する時と同等の情報の 精度を求める場合、2 倍の時間が必要になる。しか し、多くの場合、それほどの時間的余裕はなく、干 渉船 1 隻あたりの監視に割くことができる時間は減 少すると推定される。この減少が表れる指標として これらの数值があると考えた。

表 7 隻数による情報収集状況の比較

\begin{tabular}{|c|c|c|c|}
\hline & & \\
\hline & & 1 隻対 2 隻 & 1 隻対 1 隻 \\
\hline \multirow{7}{*}{$\begin{array}{l}\text { 各情報の } \\
\text { 収集割合 }\end{array}$} & vector & $20 \%$ & $13 \%$ \\
\hline & bearing & $10 \%$ & $26 \%$ \\
\hline & distance & $15 \%$ & $26 \%$ \\
\hline & course & $13 \%$ & $26 \%$ \\
\hline & speed & $14 \%$ & $3 \%$ \\
\hline & TCPA & $14 \%$ & $3 \%$ \\
\hline & $\mathrm{DCPA}$ & $14 \%$ & $3 \%$ \\
\hline \multicolumn{2}{|c|}{ 平均所要時間 } & $0: 06: 11$ & $0: 06: 34$ \\
\hline \multirow{2}{*}{$\begin{array}{l}\text { 単位時間 } \\
\text { あたりの }\end{array}$} & 情報収集行動の回数 & 0.5 & 0.5 \\
\hline & 情報収集量 & 1.9 & 1.6 \\
\hline \multirow{2}{*}{$\begin{array}{c}\text { 収集方法 } \\
\text { の割合 }\end{array}$} & 目視 & $18.7 \%$ & $60.6 \%$ \\
\hline & レーダ/ARPA & $81.3 \%$ & $39.4 \%$ \\
\hline
\end{tabular}

避航を要する干渉船が 1 隻の場合（1 隻対 1 隻） と 2 隻の場合（1 隻対 2 隻）とにおける情報収集状 況を比較するため、全フェーズの平均值を併記して 表 7 に示す。表 7 より、干渉船が 1 隻から 2 隻に増 えた場合、1 回の情報収集に要する平均所要時間は ほぼ同等で、単位時間 1 分あたりの情報収集行動の 回数は共に 0.5 回である。単位時間 1 分あたりの情 報収集量は微増または同等である。このように情報 収集に割いた時間や収集頻度には大きな变化は見ら れなかった一方、収集された情報項目の割合には変 化が認められた。特に、情報収集方法の割合におい て、目視による割合とレーダ/ARPA システムによる 割合とが逆転し、レーダ/ARPAの使用が目視の約 2 倍となる結果となった。更に、レーダ/ARPA システ ムから得られる vector、TCPA 及びDCPA といった情 報が収集される割合が高くなった。これには、海技 者が、 1 隻の情報収集に割く時間と同等の時間内に、 複数隻間の避航の優先順位付けのほか、一方を避航 することによるもう一方への影響を考慮して避航方 針を策定しなければならない必要性が影響している と考えられる。TCPA や DCPA は短時間に数值で確認 でき、上記した点を直接的に比較や推定できる情報 であるため、収集する割合が増加したと考えられる。

複数隻への対応が必要な場合、干渉船毎の動静を 把握する精度は低下しても、複数隻間における避航 の優先順位付け及び相互影響の推定に繋がる情報項 目の収集に時間を割く傾向は、ここで取り上げた干 涉船の組合せが変わっても共通すると考えられる。 ただし、更なる検証は必要である。

\section{5. 結論}

本論では、平常から安全運航を達成できる標準的 な海技者の行動分析に基づいて、航行船との衝突回 避の際の情報収集特性について検討した。詳細に検 討するため、アイカメラを利用して海技者の視線移 動状況を計測する操船シミュレータによる操船実験 を実施した。そして、本船の航行に強く干渉寸る船 舶が 1 隻の時の情報収集特性に加え、干涉船が複数 隻となった場合の変化を検討した。検討にあたり、 情報の収集過程を経過時間で正規化し、初認・継続 監視・避航行動開始直前の 3 段階のフェーズに分割 した上、見合い関係毎に検討した。本論で検討した 主要な事項は次のとおりである。 
（1）各フェーズにおいて、海技者が情報収集を行う 目的を整理し、目的の達成に必要な情報項目に ついて仮説を立てた。そして、各フェーズにお ける情報収集の目的は共通でも、避航行動開始 直前フェーズでは、見合い関係に応じて目的の 達成に必要な情報項目は異なることを検討した。

（2）提案した仮説に対して、海技者が重点的に収集 した情報項目を比較して検証し、干渉船が 1 隻 の場合、仮説と概ね一致する結果を得た。

（3）初認及び継続監視フェーズで収集が必要である と仮説を立てた情報項目のうち、仮説とは異な って収集が少なかった DCPA について考察した。 考察の際、DCPA の代わりに bearing が多く収集 されていた横切り船及び行会い船の関係に着目 し、bearing は本船と干渉船との針路交差角に依 存して変化するため、単一の情報による将来の 干渉関係の推定は難しい場合があることを示し た。そして、将来の干渉関係の推定には、干渉 関係が変化する特性に応じて目的に合致する複 数の情報を組み合わせて収集し、確認すること が重要であることを指摘した。

（4）干渉船が複数の場合、 1 隻対 1 隻の場合に比べて レーダ/ARPA による情報収集の割合が増えるこ とが観測された。このことに関する考察から、 干渉船毎の動静を把握する精度は低下しても、 複数隻間における避航の優先順位付け及び相互 影響の推定に繋がる情報項目の収集に時間を割 く必要性から、収集する情報項目の種類は変化 する可能性があることを指摘した。

\section{参考文献}

（1）馮天承ほか：アイカメラを用いた操船者の情報 収集特性に関する研究 - 衝突回避操船における 情報収集特性一，日本航海学会講演予稿集，2 巻, 1 号, 2014

(2) Odd Sveinung Hareide, Runar Ostnes : Maritime Usability Study by Analysing Eye Tracking Data, The Journal of Navigation, The Royal Institute of Navigation, Volume 70, Issue 5, pp. 927-943, 2017

(3) Ai Sakakibara, Akiko Uchino, Hiroaki Kobayashi : Study on the Characteristics of
Collecting Information by Young Mariners Analysis Using the Eye Tracer Camera - , Proceedings of 15th Asian Conference on Marine Safety and System Research, pp. 105-114, 2015

(4) Ai Sakakibara, Akiko Uchino, Hiroaki Kobayashi : The Characteristics of Collecting Information for Collision Avoiding Maneuver, Proceedings of 16th Asian Conference on Marine Safety and System Research, pp. 75-83, 2016 